\title{
The end of a myth - Bt (Cry1Ab) maize does not harm green lacewings
}

\author{
Jörg Romeis ${ }^{1 *}$, Michael Meissle ${ }^{1}$, Steven E. Naranjo ${ }^{2}$, Yunhe Li $^{1,3}$ and Franz Bigler ${ }^{1}$ \\ ${ }^{1}$ Agroscope, Institute for Sustainability Sciences ISS, Zurich, Switzerland \\ 2 USDA-ARS, Arid Land Agricultural Research Center, Maricopa, AZ, USA \\ ${ }^{3}$ State Key Laboratory for Biology of Plant Diseases and Insect Pests, Institute of Plant Protection, Chinese Academy of Agricultural Sciences, Beijing, China
}

\section{Edited by:}

Richard Sayre, New Mexico

Consortium at Los Alamos National

Labs, USA

Reviewed by:

T. J. Higgins, CSIRO, Australia

Ramon Albajes, Universitat de

Lleida, Spain

*Correspondence:

Jörg Romeis, Agroscope, Institute

for Sustainability Sciences ISS,

Reckenholzstr. 191, 8046 Zurich,

Switzerland

e-mail: joerg.romeis@

agroscope.admin.ch
A concern with Bt-transgenic insect-resistant plants is their potential to harm non-target organisms. Early studies reported that Cry1Ab-producing Bt maize and purified Cry1Ab harmed larvae of the green lacewing, Chrysoperla carnea. Although these effects could not be confirmed in subsequent studies, some authors still refer to them as evidence that Bt maize harms beneficial species. We provide a comprehensive review of the studies evaluating the effects of $\mathrm{Bt}(\mathrm{Cry} 1 \mathrm{Ab})$ maize on $\mathrm{C}$. carnea. The evidence indicates that this important predator is not affected by Bt maize or by the produced Cry1Ab protein. We discuss how conceptual models can assist environmental risk assessments, and we emphasize the importance of robust and reproducible studies.

Keywords: Chrysoperla carnea, environmental risk assessment, meta-analyses, non-target effects, study design

\section{INTRODUCTION}

One concern with the growing of genetically modified (GM) maize that produces insecticidal Cry proteins from the bacterium Bacillus thuringiensis (so-called Bt maize, Box $\mathbf{1}$ ) is that the insecticidal proteins may harm non-target organisms that provide important ecosystem services including biological control, pollination, and decomposition. Organisms providing these services must be protected from unacceptable adverse effects of pest control measures, i.e., they are classified as "protection goals" (Nienstedt et al., 2012; Sanvido et al., 2012; Garcia-Alonso and Raybould, 2013). Effects on such protected entities are thus addressed in the environmental risk assessment that precedes the approval for cultivation of new GM plants (Garcia-Alonso et al., 2006; OECD, 2007; Rose, 2007; Romeis et al., 2008; Devos et al., 2014).

In 1998, Hilbeck et al. reported that Cryl Ab-producing Bt maize (event Bt11) and pure CrylAb protein harmed larvae of the green lacewing Chrysoperla carnea (Neuroptera: Chrysopidae) (Hilbeck et al., 1998a,b), a common predator in many crop and non-crop habitats (Box 2). These results received considerable attention in the scientific and popular press, particularly in Europe. They were the first indication of adverse effects of Lepidoptera-active Bt maize on a beneficial species unrelated to the target organisms. Those reports have been repeatedly used as evidence of environmental risks related to the use of Bt maize. Authorities in Greece (EFSA, 2006) and Austria (EFSA, 2008), for example, cited them when invoking a safeguard clause in European genetic technology legislation to suspend the approval of MON810.

Since these initial reports by Hilbeck et al. (1998a,b), numerous studies with green lacewings and $\mathrm{Bt}$ maize have been conducted. We here compile all available evidence regarding Bt maize effects on green lacewings. In contrast to the initial reports, we provide evidence that $\mathrm{Bt}$ maize producing Cryl Ab does not harm this important insect predator. We believe that the evidence available today should end the debate about Bt maize effects on green lacewings and that the case of the green lacewing can provide guidance on how findings from laboratory or field experiments with other non-target species should be placed into a risk assessment context.

\section{IMPACT OF Bt MAIZE ON C. CARNEA}

Two main hypotheses can be formulated on how Bt maize could cause harm to C. carnea and its biological control function. First, the intended production of the insecticidal Cryl Ab protein could result in direct or indirect harm. Second, the genetic modification of the maize plant could have resulted in unpredictable and unintended adverse changes.

For the assessment of potential direct toxic effects, we construct a "pathway to harm" as a conceptual model that assists in formulating and testing specific risk hypotheses (Figure 2) (Raybould, 2010; Gray, 2012). Steps 1-3 concern the CrylAb level that lacewings are exposed to in Bt maize fields; Steps 4 and 5 concern hazard characterization; and Steps 6 and 7 relate to the consequences of hazard and exposure. Using published data, we will discuss these steps for C. carnea larvae and adults. Subsequently, we also discuss the potential importance of indirect, food-web related effects and briefly address transformation related effects.

\section{DIRECT TOXIN EFFECTS \\ STEP 1. Bt PROTEIN IS CONTAINED IN PREY/FOOD OF LACEWINGS}

Cry proteins from $\mathrm{Bt}$ are gut active and thus toxic only after ingestion. Step 1 assesses whether the prey/food of lacewings contains the insecticidal compound. 


\section{Box 1 | Bt maize.}

Genetically modified (GM) maize expressing the cry1Ab gene derived from the bacterium Bacillus thuringiensis (Bt) was first commercialized in 1996. In 2013, maize producing Cry1Ab was cultivated on millions of hectares in the Americas, South Africa, the Philippines, and Europe (mainly Spain) (James, 2013).

Bt maize containing Cry1 Ab is protected from major lepidopteran pests such as the European corn borer (Ostrinia nubilalis; Crambidae), the Asian corn borer (Ostrinia furnacalis; Crambidae), and the Mediterranean corn borer (Sesamia nonagrioides; Noctuidae) (Hellmich et al., 2008).

At present, three transformation events that express cry1Ab have been developed (CERA, 2012). The most common event that is commercialized in the countries listed above is MON810. A second event, Bt11, is grown in most of those countries but has been waiting approval for cultivation in the European Union since 1996. The third event, Bt176, was cultivated from 1996 to 2007. In addition, stacked events that contain MON810 and/or Bt11 are cultivated or in the approval process (CERA, 2012; EFSA, 2013).

Plants carrying any of the three events do not differ greatly in the cry $1 \mathrm{Ab}$ expression levels in green plant tissue (leaves). The amount of Cry1 Ab in leaves of the different transformation events typically ranges from 1 to $17 \mu \mathrm{g} / \mathrm{g}$ fresh weight (FW) (Obrist et al., 2006a; Nguyen and Jehle, 2007; Székács et al., 2010). In contrast, Cry1Ab levels in pollen significantly differ among events. While concentrations in pollen from Bt176 were reported to range from 5 to $11 \mu \mathrm{g} / \mathrm{g} \mathrm{FW}$, levels in today's Bt maize events MON810 and Bt11 are much lower, i.e., in the ng/g range (Dutton et al., 2003b; Obrist et al., 2006c; Nguyen and Jehle, 2007; Li et al., 2008).

\section{Box 2 | Green lacewings.}

Green lacewings in the genus Chrysoperla (Neuroptera: Chrysopidae) are widespread in agricultural areas worldwide (Figures 1A,B). The species are valued because the larvae are predators of small soft-bodied arthropods and thus contribute to the biological control of crop pests. The adults feed predominately on pollen, nectar, and homopteran honeydew. The most common species found throughout Europe is Chrysoperla carnea (Duelli, 2001; Meissle et al., 2012; Romeis et al., 2014). For the purpose of this paper, the name C. carnea is used for the carnea species group that includes a complex of cryptic, sibling species that are reproductively isolated by their mating songs (Duelli, 2001; Henry et al., 2001).
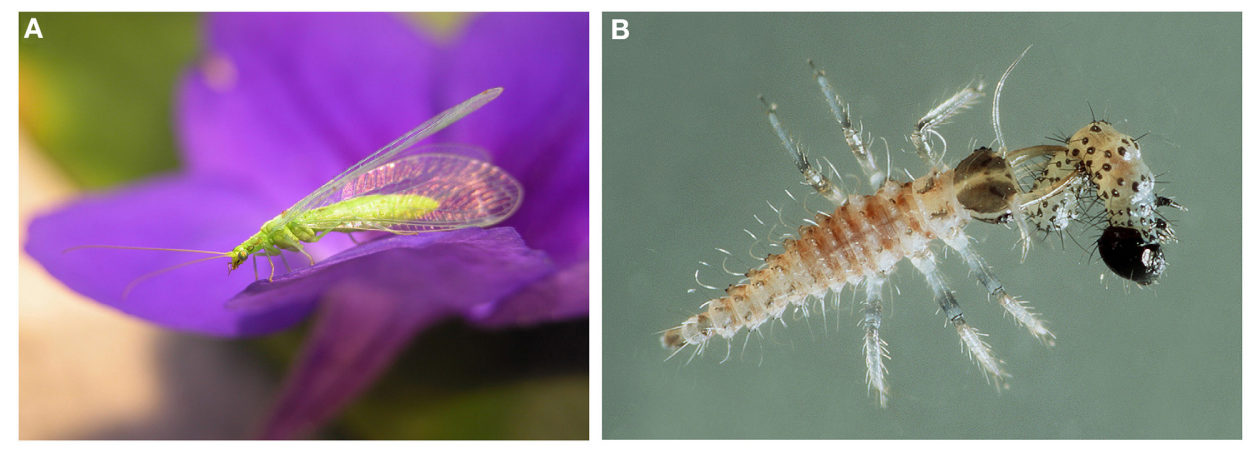

FIGURE 1 | Adult (A) and Larva (B) of the green lacewing Chrysoperla carnea. Photos: Agroscope (A, Mario Waldburger; B, Gabriela Brändle).

\section{Larvae}

C. carnea larvae are generalist predators that feed on soft-bodied arthropods but especially on aphids and other homopterans. They have been reported to feed on $>70$ prey species in six arthropod orders (Balduf, 1939; Herard, 1986).

Analyses of Bt maize-collected herbivores that are considered prey for $C$. carnea confirmed that they contain Cry proteins (Harwood et al., 2005; Obrist et al., 2006a; Meissle and Romeis, 2009a). Three facts are evident: (i) phloem-feeders, like aphids, contain no or only trace amounts of Cry protein when feeding on CrylAb-producing Bt maize (Romeis and Meissle, 2011) and CrylAb is not readily transported in the phloem of events Bt11 and Bt176 (Raps et al., 2001); (ii) spider mites such as Tetranychus urticae (Acarina: Tetranychidae) contain levels of Cry1Ab generally similar to those in green maize leaves (Dutton et al., 2002; Obrist et al., 2006b; Alvarez-Álfageme et al, 2008); (iii) Cry protein levels are considerably lower in other arthropods including tissue-feeding caterpillars and thrips than in plant tissue. While C. carnea larvae can utilize maize pollen and likely consume pollen during anthesis (Pilcher et al., 1997; Meissle et al., 2014), pollen in current Bt maize events contains very low levels of CrylAb (see below).

\section{Adults}

In contrast to larvae, C. carnea adults are not predaceous and feed mainly on pollen, nectar, and honeydew (Sheldon and MacLeod, 1971; Principi and Canard, 1984; Villenave et al., 2006; Hogervorst et al., 2007). Nectar and honeydew can be excluded as exposure routes; maize does not produce nectar, and aphid honeydew will not contain the Cry protein given that the aphids do not ingest the protein (Romeis and Meissle, 2011). Pollen, however, could expose adult C. carnea to CrylAb. Females in 


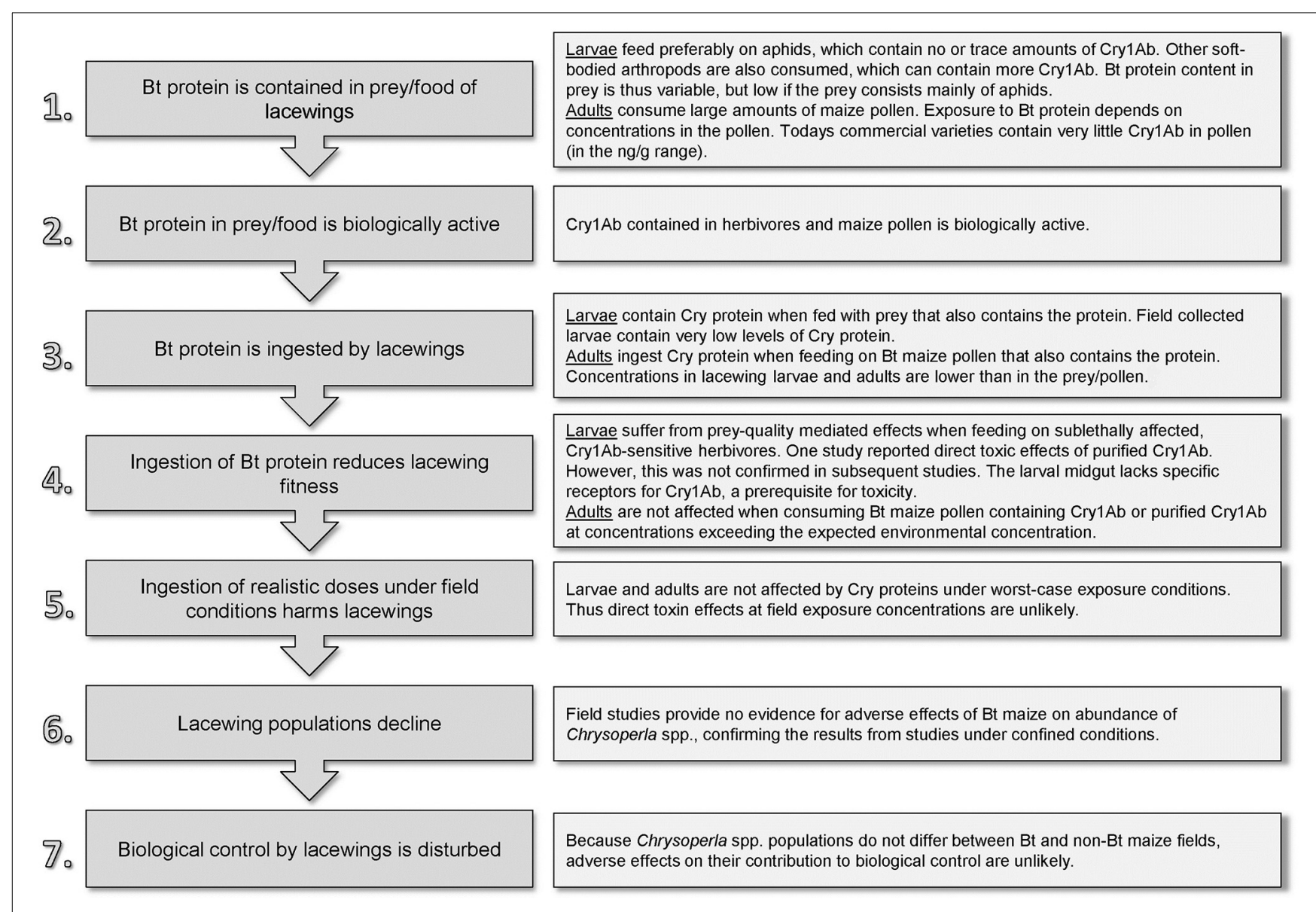

FIGURE 2 | The pathway of how Bt (Cry1Ab) maize might directly harm Chrysoperla carnea and a summary of published findings.

particular require pollen as a protein source for egg production (Li et al., 2008, 2010). Maize produces large amounts of pollen but pollen is available for $\leq 2$ weeks in a maize field and $\leq 4$ weeks in the surrounding landscape (Sears et al., 2001). Investigations in a flowering Swiss maize field found that all female lacewings collected during maize anthesis contained maize pollen (Li et al., 2010). Based on pollen counts in the female gut and the duration of gut passage, a female lacewing was estimated to consume up to 10,000 maize pollen grains per day at peak flowering (Li et al., 2010). While pollen of Bt maize is known to contain Cryl Ab, levels vary among events. Levels detected in MON810 and Bt11 pollen are in the ng/g range but levels more than 100-times greater than this occur in Bt176 pollen (Box 1).

\section{STEP 2. Bt PROTEIN IN PREY/FOOD IS BIOLOGICALLY ACTIVE}

The Cry protein contained in the food consumed by lacewings must be biologically active to cause harm.

\section{Larvae}

Feeding studies with sensitive caterpillars have revealed that the CrylAb protein in larvae of Spodopera littoralis (Lepidoptera: Noctuidae) or in T. urticae that consumed Bt maize (Bt 11) has the same biological activity as the toxin in the plant (Obrist et al., 2006b). Similarly, bioactivity of Cry proteins has been confirmed in sensitive insect bioassays for various other combinations of $\mathrm{Bt}$ plants, Cry proteins, and herbivores (Chen et al., 2008; Meissle and Romeis, 2009b; Li et al., 2011; Liu et al., 2011; Tian et al., 2012, 2013).

\section{Adults}

The biological activity of Cryl $\mathrm{Ab}$ in maize pollen from transformation events Bt176, Bt11, and MON810 has been confirmed in assays with sensitive insects (Hellmich et al., 2001; Dively et al., 2004; Anderson et al., 2005).

\section{STEP 3. Bt PROTEIN IS INGESTED BY LACEWINGS}

Even though the food items consumed by lacewings contain CrylAb, whether the insects actually ingest the toxin when feeding should be confirmed, especially in the case of lacewing larvae. First, prey may contain CrylAb in their gut but the lacewing larvae may feed on the haemolymph. Second, larvae may use extra-oral digestion, albeit at a low level (Yazlovetsky, 2001), that could partially degrade the Bt protein before it enters the lacewing gut.

\section{Larvae}

Tri-trophic laboratory studies using S. littoralis larvae, T. urticae, and Frankliniella tenuicornis (Thysanoptera: Thripidae) as prey 
confirmed a flow of CrylAb from Bt maize to the herbivores and subsequently to the C. carnea larvae (Obrist et al., 2005, 2006b). The Cry1Ab concentration detected in C. carnea larvae was related to the toxin content in the prey and to the quantity of prey ingested. The CrylAb concentration detected in the predator was about half the concentration in the prey. This relatively small drop in concentration might be explained by the short duration of the feeding experiment and the fact that little of the ingested Cryl $\mathrm{Ab}$ may have been digested in the lacewing gut. That C. carnea larvae ingest Cry protein when feeding on Bt-containing herbivores has been reported from other tri-trophic study systems (Wei et al., 2008; Lawo et al., 2010) and another lacewing species, Chrysoperla rufilabris (Neuroptera: Chrysopidae) (Tian et al., 2013).

Few studies have quantified Bt Cry proteins in field-collected C. carnea larvae. Obrist et al. (2006a) reported levels below $0.01 \mu \mathrm{g}$ of CrylAb/g dry weight (DW) in larvae collected from a Bt maize field (Bt176) in Spain before and during pollen shedding. Levels were higher (around $0.5 \mu \mathrm{g} / \mathrm{g} D W$ ) after pollen shedding, probably because of the presence of spider mite prey that are known to contain high amounts of Cry protein (see above). No CrylAb was detected in two C. carnea samples collected in a Bt maize field (Bt11) (Harwood et al., 2005). In a Cry3Bb1-producing Bt maize field, C. carnea larvae contained $1.05 \pm 0.932 \mu \mathrm{g}$ of Cry3Bb1/g DW (Meissle and Romeis, 2009a). Overall, levels detected in field-collected C. carnea larvae were extremely low when compared to other predatory arthropods (Harwood et al., 2005; Obrist et al., 2006a; Meissle and Romeis, 2009a), probably because their main prey, i.e., aphids, do not contain CrylAb.

\section{Adults}

Li et al. (2010) quantified the amount of Cry protein that adult C. carnea would be exposed to when consuming only $\mathrm{Bt}$ maize pollen. Considering the number of pollen grains consumed by a female in a flowering maize field and the toxin concentration measured in pollen from Bt176, a female would ingest $22.6 \mathrm{ng}$ of CrylAb per day (Li et al., 2010). The pollen grains are only partly digested during gut passage, and up to $40 \%$ of the Cry protein remains in the pollen grains that are excreted (Li et al., 2010).

Only one study has analyzed the CrylAb content in adult C. carnea collected in a Bt maize field (Bt176). Insects collected during anthesis contained about $0.5 \mu \mathrm{g} / \mathrm{g}$ DW (Obrist et al., 2006a). For comparison, in a Cry3Bb1-expressing Bt maize field (MON88017), adults contained $1.53 \pm 0.402 \mu \mathrm{g}$ of $\mathrm{Cry3Bb} 1 / \mathrm{g}$ DW (Meissle and Romeis, 2009a). This difference could be explained by the substantially higher Cry protein concentrations in MON88017 compared with Bt176 pollen (Obrist et al., 2006a; Meissle and Romeis, 2009a).

\section{STEP 4. INGESTION OF Bt PROTEIN REDUCES LACEWING FITNESS}

Several studies assessed the toxicity of CrylAb to C. carnea larvae or adults.

\section{Larvae}

C. carnea larvae were exposed to Cry1Ab directly through artificial diet or indirectly through the provisioning of Bt maize-fed herbivores (tri-trophic studies).

\section{Direct studies}

Laboratory studies (Hilbeck et al., 1998a) revealed adverse effects of CrylAb on C. carnea larvae. The test compound was mixed into an artificial diet of unknown composition. When larvae were continuously fed the artificial diet containing CrylAb at a nominal concentration of $100 \mu \mathrm{g} / \mathrm{ml}$ diet, pre-imaginal mortality was $57 \%$ as compared with $30 \%$ in the untreated control. The control mortality in these studies was unusually high (Van Emden, 1999; Vogt et al., 2000), indicating problems in study design, artificial diet, or test insects (Romeis et al., 2011). In two subsequent studies, which followed a different approach, C. carnea larvae were provided with CrylAb dissolved in a sucrose solution only during the first day of each of the three larval stages (Romeis et al., 2004; Lawo and Romeis, 2008). At all other times, larvae were fed with Ephestia kuehniella (Lepidoptera: Pyralidae) eggs to allow their development. Consequently, larvae were not continuously exposed to CrylAb. To account for this, CrylAb was provided in high nominal concentrations of up to $0.1 \%$ Cry $1 \mathrm{Ab} / \mathrm{ml}$ sucrose solution (w/v). Neither study observed any adverse effects of the CrylAb treatment. Further evidence for a lack of effect of CrylAb on C. carnea larvae was provided by Rodrigo-Simón et al. (2006), who did not observe binding of the Cry protein to lacewing gut membranes, a prerequisite for toxicity of Bt proteins (Schnepf et al., 1998), in either histopathological or in vitro binding studies. Recent feeding studies with CrylAb containing pollen from Bt maize (Bt176, MON810) did not reveal adverse effects on the mortality or the development time of $C$. carnea larvae when compared to pollen from non-transformed near-isolines (Meissle et al., 2014). An artificial diet study also reported that CrylAb did not affect C. sinica larvae (Li et al., 2014a).

\section{Tri-trophic studies}

In these studies, Bt maize-fed arthropods were used to expose the lacewing larvae to CrylAb. Adverse effects on larval survival and development occurred when CrylAb-sensitive O. nubilalis or S. littoralis caterpillars were used as prey (Hilbeck et al., 1998a, 1999; Dutton et al., 2002). In contrast, C. carnea larvae were not affected when non-sensitive spider mites, T. urticae, were used as prey even though they contained about 3.5-times higher CrylAb concentrations than $S$. littoralis larvae $(2.5 \mathrm{vs} .0 .72 \mu \mathrm{g}$ of CrylAb/g FW) (Dutton et al., 2002). Because the CrylAb contained in T. urticae and $S$. littoralis larvae is biologically active (see above), the effects observed when using CrylAb-sensitive caterpillars as prey were likely caused by reduced nutritional quality of sublethally affected caterpillars. Two studies provide further evidence. First, the same negative effects on $C$. carnea larvae were observed when the caterpillar prey had fed on nontransgenic plants that had been treated with a Bt spray product (Dutton et al., 2003a). Second, Lawo et al. (2010) observed adverse effects when the C. carnea larvae were fed with CrylAcsensitive Helicoverpa armigera (Lepidoptera: Noctuidae) caterpillars that had consumed Bt (CrylAc) cotton. The predator larvae remained unaffected, however, when provided with Bt cotton-fed caterpillars from a CrylAc-resistant strain of $H$. armigera even though C. carnea larvae ingested 3.5-times more CrylAc when consuming resistant caterpillars than susceptible ones. These examples demonstrate that objectives must be clearly formulated 
and experiments carefully designed. Prey quality-mediated effects have been observed in numerous tri-trophic feeding studies with Bt-transgenic crops and a range of natural enemies (Romeis et al., 2006; Naranjo, 2009).

In summary, while early studies suggested direct toxic effects of CrylAb on C. carnea larvae, these effects were not confirmed in follow-up studies. Adverse effects in tri-trophic studies appear to be due to changes in prey quality rather than to CrylAb toxicity. The potential ecological relevance of such indirect CrylAbrelated effects are discussed below.

\section{Adults \\ Adult survival, pre-oviposition period, fecundity, fertility, and dry weight were similar when adults were fed a pure artificial diet or an artificial diet containing CrylAb at a nominal concentra- tion of $120 \mu \mathrm{g} / \mathrm{g}$ DW (measured concentration: 47-55 $\mu \mathrm{g} / \mathrm{g} \mathrm{DW}$ ), or when fed non-Bt maize pollen or Bt maize (Bt176) pollen containing CrylAb at $10 \mu \mathrm{g} / \mathrm{g}$ DW (Li et al., 2008). For com- parison, pollen of today's Bt maize events MON810 and Bt11 contains Cry1Ab at levels that are at least 50-times lower (see above). These findings strongly suggest that $C$. carnea adults are not affected when feeding on Bt maize pollen. Similarly, Mason et al. (2008) provided no evidence for adverse effects of CrylAb-containing Bt maize pollen on longevity, fecun- dity, or fertility of adult Chrysoperla plorabunda (Neuroptera: Chrysopidae).}

\section{STEP 5. INGESTION OF REALISTIC DOSES UNDER FIELD CONDITIONS HARMS LACEWINGS}

While Steps 1-4 addressed the potential of C. carnea larvae and adults to be exposed to biologically active CrylAb in a Bt maize field and the potential sensitivity (hazard) to CrylAb, Step 5 assesses whether C. carnea larvae or adults are affected by Cry1 Ab at concentrations encountered under field conditions.

\section{Larvae \\ Under worst-case exposure conditions, only one study has sug- gested a direct toxic effect of Cry1Ab on C. carnea larvae, an effect that could not be confirmed in subsequent studies (see Step 4 above). Together with the fact that exposure of larvae is likely to be negligible through their preferred aphid prey (see Step 1), this indicates that larvae are unlikely to be affected by realistic field concentrations of CrylAb.}

\section{Adults}

For adults, no sensitivity to CrylAb under worst-case exposure conditions has been observed (see Step 4 above). This together with the fact that the pollen from today's Bt maize events contains only low levels of Cry1 Ab and that maize pollen is only available for a limited time suggests that adults are unlikely to be affected by realistic concentrations of CrylAb.

\section{STEPS 6. LACEWING POPULATIONS DECLINE}

Lacewing populations (Chrysoperla spp. or Chrysopidae incl. Chrysoperla spp.) in Bt (CrylAb) and non-Bt maize have been compared in 13 field studies. We subjected the data to a metaanalysis to determine whether lacewing abundance differs in untreated Bt maize and non-Bt maize that was treated with insecticide or left untreated (Box 3). Chrysopidae abundance did not significantly differ between Bt maize, and non-Bt maize without or with insecticide. Chrysoperla spp. abundance did not differ between $\mathrm{Bt}$ and non-Bt maize without insecticides, but was significantly higher in Bt maize without insecticides than in non-Bt maize with insecticide. Overall, the meta-analysis indicates that lacewing abundance is not reduced in Bt-maize fields. A recent meta-analysis with data from experiments with Lepidopteraresistant Bt maize conducted in Spain has confirmed this lack of effects (Comas et al., 2014). Similar observations have been made for many other natural enemies (Wolfenbarger et al., 2008; Naranjo, 2009).

\section{STEP 7. BIOLOGICAL CONTROL BY LACEWINGS IS DISTURBED}

Biological control by C. carnea or other lacewings has not been directly studied in Bt maize fields. Given a lack of populationlevel effects, disturbance of biological control is not expected. This is supported by evidence from Bt (CrylAc) cotton (Naranjo, 2005). Predation of Bemisia tabaci (Hemiptera: Aleyrodidae) nymphs was unchanged in Bt cotton where Chrysoperla spp. is an important predator (Naranjo and Ellsworth, 2005).

In addition, even if green lacewing abundance was reduced, this may not necessarily decrease biological control. For cotton, Naranjo (2005) showed that an average change of about $20 \%$ in a small number of predatory species was not ecologically meaningful in terms of the biological control potential of the natural enemy community. Furthermore, functional theory suggests that the activity of any one species in the complex can be offset by other members of the community (Walker, 1992; Naranjo, 2005).

\section{INDIRECT EFFECTS DUE T0 Cry1Ab}

As discussed above, the ingestion of CrylAb by sensitive lepidopteran larvae (but not in the case of other non-sensitive herbivores) can reduce their nutritional quality as prey for $C$. carnea larvae and thus potentially impose adverse effects. For C. carnea inhabiting Bt maize fields, we regard this risk as negligible for two main reasons. First, caterpillars are generally a rare prey for lacewing larvae in $\mathrm{Bt}$ or non-Bt maize fields. The most common species in maize are the stem-borers (Crambidae or Noctuidae) that are the targets of Bt maize (Meissle et al., 2012; Romeis et al., 2014) and are thus virtually absent. In addition, stem-borer larvae are concealed with the stem for most of their development time and thus unavailable to predators like C. carnea. Larvae of other Lepidoptera species that feed on the plant surface are also relatively rare when compared to other prey and are not a preferred food source. Choice experiments have demonstrated a clear preference of C. carnea for aphids over S. littoralis larvae (Meier and Hilbeck, 2001) and behavioral observations have revealed that more than $70 \%$ of $S$. littoralis larvae that were encountered by $C$. carnea on maize plants escaped predation (Dutton et al., 2003b). In addition, C. carnea larvae preferred non-Bt maizefed $S$. littoralis compared with Bt (CrylAb) maize-fed S. littoralis when given a choice (Meier and Hilbeck, 2001). Thus, exposure of C. carnea to sublethally affected caterpillar prey is likely to be very low. Second, available data from field experiments provide no indication that the lacewing populations decline in $\mathrm{Bt}$ 


\section{Box 3 | Evidence from field studies.}

Meta-analyses were conducted with data from field studies to compare the abundance of Chrysoperla spp. or Chrysopidae (incl. Chrysoperla spp.) in Bt (Cry1Ab) maize, and non-Bt maize that was untreated with insecticides (Figure 3A) or treated with insecticides (primarily pyrethroids) for control of the target pest (Figure 3B). The meta-analysis methodology followed the approach of Wolfenbarger et al. (2008) and Naranjo (2009). The analysis used Hedges' d, a weighted mean effect size estimator that is calculated as the difference in abundance between an experimental (Bt) and control (non-Bt) mean response divided by a pooled standard deviation and multiplied by a small sample size bias correction term. A positive effect size would indicate higher abundance in the Bt crop. In comparisons of Bt maize vs. non-Bt maize without insecticides, effect sizes were positive but they were small and did not differ from zero based on bootstrap, biascorrected 95\% confidence intervals (Figure 3A) (Rosenberg et al., 2000). In comparisons of unsprayed Bt maize vs. non-Bt maize treated with insecticides, the abundance of Chrysoperla spp. was significantly higher in Bt fields. The effect size for all Chrysopidae combined did not differ from zero (Figure 3B). The values above the bars denote the total number of observations. Data used for these meta-analyses are provided in Supplemental Table S1.
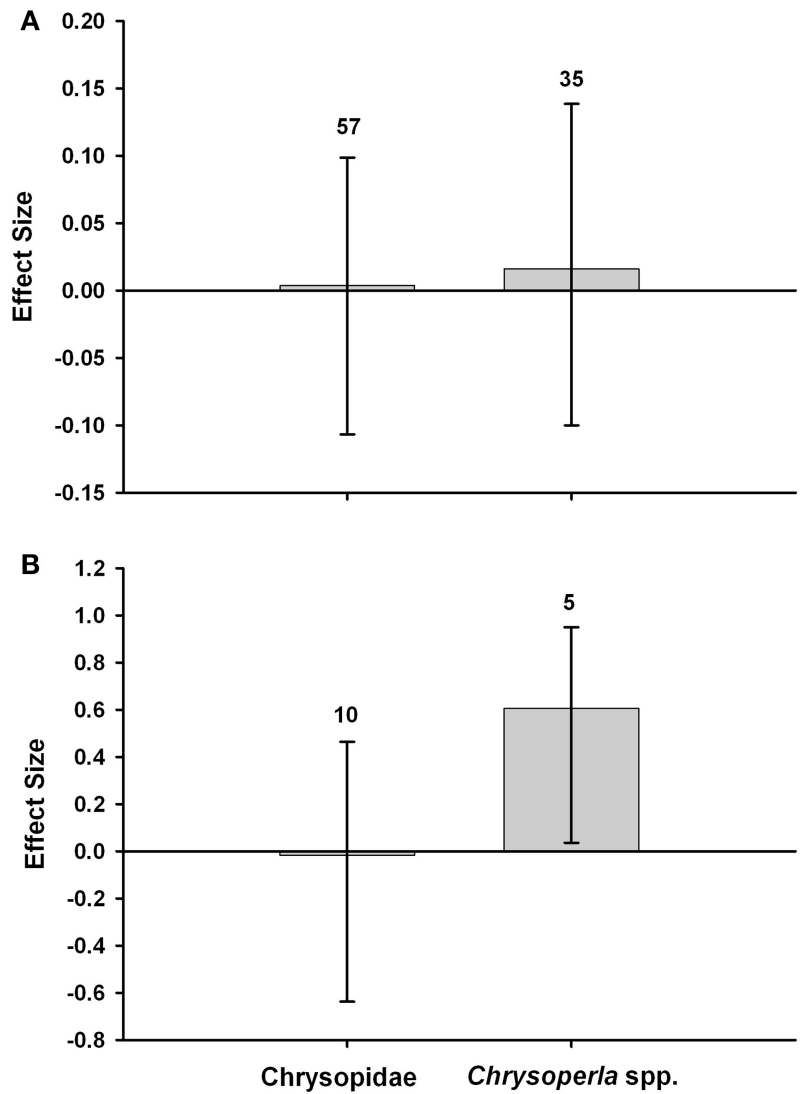

FIGURE 3 | Meta-analyses of field studies examining the abundance of lacewings in Bt maize, and non-Bt maize that was untreated with insecticide (A) or treated with insecticides (B).

maize fields compared with conventional maize (see Steps 6 and 7 above).

\section{TRANSFORMATION RELATED EFFECTS}

Since the development of the first GM plants, concerns have been expressed that harm to the environment as well as harm to animal and human health could occur as a consequence of unpredictable, unintended changes that are caused by the process of transgene insertion. This process could lead to sequence changes, production of new proteins, formation of new metabolites or altered levels of existing metabolites, thus compromising safety (Cellini et al., 2004; Herman and Price, 2013).
Consequently, any new GM plant is compared to conventional counterparts, which have a history of safe use (Garcia-Alonso, 2010). The comparative assessment is based on a molecular characterization, compositional analyses, and an agronomic/phenotypic comparison. The aim of this assessment is to identify possible differences in plant characteristics (in addition to the "intended changes") that fall outside the range of natural variation of the crop and could lead to harm. If potentially harmful unintended changes are detected, this would trigger a more detailed assessment (Romeis et al., 2008). Thus, the comparative assessment serves as a starting point to focus the environmental risk assessment process on identified stressors of concern. 
All Bt maize plants that are grown today have undergone such comparative assessments. The experience with GM plants to date has shown that the transformation process is not more likely to result in significant unintended effects compared to conventional breeding techniques. There are no known cases where plants unexpectedly produce novel toxins either after genetic transformation or as a consequence of conventional breeding. In addition, each breeding process includes several screening and selection steps that identify and eliminate plants with irregular phenotypes and composition that could cause an impact on non-target organisms (Weber et al., 2012; Herman and Price, 2013).

Surprisingly, some authors have reported an increase in aphid abundance in Bt (CrylAb) maize in Spain (Lumbierres et al., 2004; Pons et al., 2005). The factors that caused this phenomenon have not been elucidated but could be due to some unintended, transformation related effects. An increase in aphid abundance, however, is not expected to adversely affect lacewing abundance given that aphids are the preferred prey for lacewing larvae.

In summary, it is unlikely that unintended, transformation related effects could result in adverse effects on lacewings. This is supported by the fact that no adverse effects of Bt maize on the abundance of lacewings and biological control have been reported from the field (see Steps 6 and 7 above).

\section{CONCLUSIONS}

Because putative adverse non-target effects of CrylAb Bt maize on the green lacewing $C$. carnea were reported shortly after the commercial release of this GM plant, the results have received considerable attention. In this comprehensive review, we show that there is sufficient information available today to conclude that Bt maize containing CrylAb does not harm C. carnea. Similarly, there is no evidence that other Lepidoptera-active Cry1 and Cry2 proteins produced by GM maize and other plants cause direct toxic effects to Chrysoperla species (OECD, 2007; Mason et al., 2008; Tian et al., 2013; Li et al., 2013, 2014a,b). Despite this, the myth that Bt maize harms green lacewings continues to be used by opponents of GM plants, who selectively cite only those initial studies that indicated direct adverse effects (Hilbeck et al., 2008, 2012; Dolezel et al., 2009; Then, 2010; Meyer, 2011).

We believe that lessons learned from the lacewing case can improve the quality and predictability of non-target risk assessment of future insecticidal GM crops. First, scientific studies can sometimes lead to unexpected results, which should be verified by other independent research groups. As was the case with C. carnea, harmful effects of CrylAb on a few other nonLepidoptera species have been observed (Romeis et al., 2013). However, in none of the cases have the results been confirmed in follow-up studies.

Second, effects observed under laboratory conditions cannot automatically be translated into environmental harm. The development of conceptual models on how a particular GM plant could harm a valued non-target species or its ecological function assists in this process and also helps in formulating testable risk hypotheses. If studies provide convincing evidence that one of the steps in the conceptual model is unlikely, the pathway to harm is interrupted, and a negligible risk can be inferred. This requires, however, that the studies conducted are properly designed and reproducible to minimize the probability of false positives and negatives.

\section{SUPPLEMENTARY MATERIAL}

The Supplementary Material for this article can be found online at: http://www.frontiersin.org/journal/10.3389/fpls.2014.00391/ abstract

\section{REFERENCES}

Alvarez-Álfageme, F., Ferry, N., Castañera, P., Ortego, F., and Gatehouse, A. M. R. (2008). Prey mediated effects of Bt maize on fitness and digestive physiology of the red spider mite predator Stethorus punctillum Weise (Coleoptera: Coccinellidae). Transgenic Res. 17, 943-954. doi: 10.1007/s11248-008-9177-4

Anderson, P. L., Hellmich, R. L., Prasifka, J. R., and Lewis, L. C. (2005). Effects on fitness and behaviour of monarch butterfly larvae exposed to a combination of CrylAb expressing corn anthers and pollen. Environ. Entomol. 34, 944-952. doi: 10.1603/0046-225X-34.4.944

Balduf, W. V. (1939). The Bionomics of Entomophagous Insects, Part II. St Louis, MO: John S. Swift Co., Inc.

Cellini, F., Chesson, A., Colquhoun, I., Constable, A., Davies, H. V., Engel, K. H., et al. (2004). Unintended effects and their detection in genetically modified crops. Food Chem. Toxicol. 42, 1089-1125. doi: 10.1016/j.fct.2004.02.003

Center For Environmental Risk Assessment (CERA). (2012). GM Crop Database. (Washington, DC: CERA, ILSI Research Foundation). Available online: http://cera-gmc.org/index.php?action=gm_crop_database (Accessed July 31, 2014)

Chen, M., Zhao, J.-Z., Collins, H. L., Earle, E. D., Cao, J., and Shelton, A. M. (2008). A critical assessment of the effects of Bt transgenic plants on parasitoids. PLoS ONE 3:e2284. doi: 10.1371/journal.pone.0002284

Comas, C., Lumbierres, B., Pons, X., and Albajes, R. (2014). No effects of Bacillus thuringiensis maize on nontarget organisms in the field in southern Europe: a meta-analysis of 26 arthropod taxa. Transgenic Res. 23, 135-143. doi: 10.1007/s11248-013-9737-0

Devos, Y., Aguilera, J., Diveki, Z., Gomes, A., Liu, Y., Paoletti, C., et al. (2014). EFSA's scientific activities and achievements on the risk assessment of genetically modified organisms (GMOs) during its first decade of existence: looking back and ahead. Transgenic Res. 23, 1-25. doi: 10.1007/s11248-013-9741-4

Dively, G. P., Rose, R., Sears, M. K., Hellmich, R. L., Stanley-Horn, D. E., Calvin, D. D., et al. (2004). Effects on monarch butterfly larvae (Lepidoptera: Danaidae) after continuous exposure to CrylAb-expressing corn during anthesis. Environ. Entomol. 33, 1116-1125. doi: 10.1603/0046-225X-33. 4.1116

Dolezel, M., Miklau, M., Eckerstorfer, M., Hilbeck, A., Heissenberger, A., and Gaugitsch, H. (2009). Standardizing the Environmental Risk Assessment of Genetically Modified Plants in the EU. BfN Skripten 259. Bonn: Bundesamt für Naturschutz.

Duelli, P. (2001). "Lacewings in field crops", in Lacewings in the Crop Environment, eds P. McEwen, T. R. New, and A. E. Whittington (Cambridge: Cambridge University Press), 158-171.

Dutton, A., Klein, H., Romeis, J., and Bigler, F. (2002). Uptake of Bt-toxin by herbivores feeding on transgenic maize and consequences for the predator Chrysoperla carnea. Ecol. Entomol. 27, 441-447. doi: 10.1046/j.13652311.2002.00436.x

Dutton, A., Klein, H., Romeis, J., and Bigler, F. (2003a). Prey-mediated effects of Bacillus thuringiensis spray on the predator Chrysoperla carnea in maize. Biol. Control 26, 209-215. doi: 10.1016/S1049-9644(02)00127-5

Dutton, A., Romeis, J., and Bigler, F. (2003b). Assessing the risks of insect resistant transgenic plants on entomophagous arthropods: Bt-maize expressing CrylAb as a case study. BioControl 48, 611-636. doi: 10.1023/A:1026313 719424

European Food Safety Authority (EFSA). (2006). Opinion of the scientific panel on genetically modified organisms on a request from the commission related to the safeguard clause invoked by Greece according to Article 23 of Directive 2001/18/EC and to Article 18 of Directive 2002/53/EC. EFSA J. 411, 1-26. doi: 10.2903/j.efsa.2008.757

European Food Safety Authority (EFSA). (2008). Scientific opinion of the panel on genetically modified organisms on a request from the European Commission 
related to the safeguard clause invoked by Austria on maize MON810 and T25 according to Article 23 of Directive 2001/18/EC1. EFSA J. 891, 1-64. doi: 10.2903/j.efsa.2008.891

EFSA (2013). Register of Questions Database. Available online at: http://registerof questions.efsa.europa.eu/roqFrontend/questionsListLoader?panel=ALL; http:// www.transgen.de/zulassung/gvo/ (Accessed July 31, 2014).

Garcia-Alonso, M. (2010). Current challenges in environmental risk assessment: the assessment of unintended effects of GM crops on non-target organisms. IOBC/WPRS Bull. 52, 57-63.

Garcia-Alonso, M., Jacobs, E., Raybould, A., Nickson, T. E., Sowig, P., Willekens, H., et al. (2006). A tiered system for assessing the risk of genetically modified plants to non-target organisms. Environ. Biosafety Res. 5, 57-65. doi: 10.1051/ebr:2006018

Garcia-Alonso, M., and Raybould, A. (2013). Protection goals in environmental risk assessment: a practical approach. Transgenic Res. doi: 10.1007/s11248-0139760-1. [Epub ahead of print].

Gray, A. (2012). Problem formulation in environmental risk assessment for genetically modified crops: a practitioner's approach. Coll. Biosafety Rev. 6, 10-65.

Harwood, J. D., Wallin, W. G., and Obrycki, J. J. (2005). Uptake of Bt endotoxins by nontarget herbivores and higher order arthropod predators: molecular evidence from a transgenic corn agroecosystem. Mol. Ecol. 14, 2815-2823. doi: 10.1111/j.1365-294X.2005.02611.x

Hellmich, R. L., Albajes, R., Bergvinson, D., Prasifka, J. R., Wang, Z.-Y., and Weiss, M. J. (2008). "The present and future role of insect-resistant genetically modified maize in IPM," in Integration of Insect-Resistant Genetically Modified Crops within IPM Programs, eds J. A Romeis, A. M. Shelton, and G. G. Kennedy (Springer Science + Business Media B.V), 119-158.

Hellmich, R. L., Siegfried, B. D., Sears, M. K., Stanley-Horn, D. E., Mattila, H. R., Spencer, T., et al. (2001). Monarch larvae sensitivity to Bacillus thuringiensis purified proteins and pollen. Proc. Nat. Acad. Sci. U.S.A. 98, 11925-11930. doi: 10.1073/pnas. 211297698

Henry, C. S., Brooks, S. J., Thierry, D., Duelli, P., and Johnson, J. B. (2001). “The common green lacewing (Chrysoperla carnea s. lat.) and the sibling species problem," in Lacewings in the Crop Environment, eds P. McEwen, T. R. New, and A. E. Whittington, (Cambridge: Cambridge University Press), 29-42.

Herard, F. (1986). Annotated list of the entomophagous complex associated with pear psylla, Psylla pyri (L.) (Hom.: Psyllidae) in France. Agronomie 6, 1-34. doi: 10.1051/agro:19860101

Herman, R. A., and Price, W. D. (2013). Unintended compositional changes in genetically modified (GM) crops: 20 years of research. J. Agric. Food Chem. 61, 11695-11701. doi: 10.1021/jf400135r

Hilbeck, A., Baumgartner, M., Fried, P. M., and Bigler, F. (1998a). Effects of transgenic Bacillus thuringiensis corn-fed prey on mortality and development time of immature Chrysoperla carnea (Neuroptera: Chrysopidae). Environ. Entomol. 27, 480-487.

Hilbeck, A., Jänsch, S., Meier, M., and Römbke, J. (2008). Analysis and Validation of Present Ecotoxicological Test Methods and Strategies for the Risk Assessment of Genetically Modified Plants. BfN Skripten 236. Bonn: Bundesamt für Naturschutz.

Hilbeck, A., Meier, M., and Trtikova, M. (2012). Underlying reasons of the controversy over adverse effects of Bt toxins on lady beetle and lacewing larvae. Env. Sci. Europe 24:9. doi: 10.1186/2190-4715-24-9

Hilbeck, A., Moar, W. J., Pusztai-Carey, M., Filippini, A., and Bigler, F. (1998b). Toxicity of Bacillus thuringiensis CrylAb toxin to the predator Chrysoperla carnea (Neuroptera: Chrysopidae). Environ. Entomol. 27, 1255-1263.

Hilbeck, A., Moar, W. J., Pusztai-Carey, M., Filippini, A., and Bigler, F. (1999). Prey-mediated effects of CrylAb toxin and protoxin and Cry2A protoxin on the predator Chrysoperla carnea. Entomol. Exp. Appl. 91, 305-316. doi: 10.1046/j.1570-7458.1999.00497.x

Hogervorst, P. A. M., Wäckers, F. L., and Romeis, J. (2007). Detecting nutritional state and food source use in field-collected insects that synthesize honeydew oligosaccharides. Funct. Ecol. 21, 936-946. doi: 10.1111/j.13652435.2007.01297.x

James, C. (2013). Global Status of Commercialized Biotech/GM Crops: 2013. ISAAA Brief No. 46. Ithaca, NY: ISAAA.

Lawo, N. C., and Romeis, J. (2008). Assessing the utilization of a carbohydrate food source and the impact of insecticidal proteins on larvae of the green lacewing, Chrysoperla carnea. Biol. Control 44, 389-398. doi: 10.1016/j.biocontrol.2007.12.002

Lawo, N. C., Wäckers, F. L., and Romeis, J. (2010). Characterizing indirect prey-quality mediated effects of a $B t$ crop on predatory larvae of the green lacewing, Chrysoperla carnea. J. Insect Physiol. 56, 1702-1710. doi: 10.1016/j.jinsphys.2010.06.012

Li, Y., Hu, L., Romeis, J., Chen, X., and Peng, Y. (2014b). Bt rice producing CrylC protein does not have direct detrimental effects on the green lacewing Chrysoperla sinica (Tjeder). Environ. Toxicol. Chem. 33, 1391-397. doi: 10.1002/etc. 2567

Li, Y., Hu, L., Romeis, J., Wang, Y., Han, L., Chen, X., et al. (2014a). Use of an artificial diet system to study the toxicity of gut-active insecticidal compounds on larvae of the green lacewing Chrysoperla sinica. Biol. Control 69, 45-51. doi: 10.1016/j.biocontrol.2013.10.017

Li, Y., Meissle, M., and Romeis, J. (2008). Consumption of Bt maize pollen expressing CrylAb or Cry3Bb1 does not harm adult green lacewings, Chrysoperla carnea (Neuroptera: Chrysopidae). PLoS ONE 3:e2909. doi: 10.1371/journal.pone.0002909

Li, Y., Meissle, M., and Romeis, J. (2010). Use of maize pollen by adult Chrysoperla carnea (Neuroptera: Chrysopidae) and fate of Cry proteins in Bt-transgenic varieties. J. Insect Physiol. 56, 157-164. doi: 10.1016/j.jinsphys.2009.09.011

Li, Y., Romeis, J., Wang, P., Peng, Y., and Shelton, A. M. (2011). A comprehensive assessment of the effects of Bt cotton on Coleomegilla maculata demonstrates no detrimental effects by Cry1Ac and Cry2Ab. PLOS ONE 6:e22185. doi: 10.1371/journal.pone.0022185

Li, Y., Wang, Y., Romeis, J., Liu, Q., Lin, K., Chen, X., et al. (2013). Bt rice expressing Cry2Aa does not cause direct detrimental effects on larvae of Chrysoperla sinica. Ecotoxicology 22, 1413-1421. doi: 10.1007/s10646-013-1127-0

Liu, X., Chen, M., Onstad, D., Roush, R., and Shelton, A. M. (2011). Effect of Bt broccoli and resistant genotype of Plutella xylostella (Lepidoptera: Plutellidae) on development and host acceptance of the parasitoid Diadegma insulare (Hymenoptera: Ichneumonidae). Transgenic Res. 20, 887-897. doi: 10.1007/s11248-010-9471-9

Lumbierres, B., Albajes, R., and Pons, X. (2004). Transgenic Bt maize and Rhopalosiphum padi (Hom. Aphididae) performance. Ecol. Entomol. 29, 309-317. doi: 10.1111/j.0307-6946.2004.00597.x

Mason, C. E., Sheldon, J. K., Pesek, J., Bacon, H., Gallusser, R., Radke, G., et al. (2008). Assessment of Chrysoperla plorabunda longevity, fecundity, and masonegg viability when adults are fed transgenic Bt corn pollen. J. Agric. Urban Entomol. 25, 265-278. doi: 10.3954/1523-5475-25.4.265

Meier, M. S., and Hilbeck, A. (2001). Influence of transgenic Bacillus thuringiensis corn-fed prey on prey preference of immature Chrysoperla carnea (Neuroptera: Chrysopidae). Basic Appl. Ecol. 2, 35-44. doi: 10.1078/1439-1791-00034

Meissle, M., Álvarez-Alfageme, F., Malone, L. A., and Romeis, J. (2012). Establishing a Database of Bio-ecological Information on Non-target Arthropod Species to Support the Environmental Risk Assessment of Genetically Modified Crops in the EU. Supporting Publications 2012:EN-334. Parma: European Food Safety Authority (EFSA). Available online: http://www.efsa.europa.eu/en/supporting/ pub/334e.htm (Accessed July 31, 2014)

Meissle, M., and Romeis, J. (2009a). The web-building spider Theridion impressum (Araneae: Theridiidae) is not adversely affected by $B t$ maize resistant to corn rootworms. Plant Biotechnol. J. 7, 645-656. doi: 10.1111/j.14677652.2009.00431.x

Meissle, M., and Romeis, J. (2009b). Insecticidal activity of Cry3Bb1 expressed in $B t$ maize on larvae of the Colorado potato beetle, Leptinotarsa decemlineata (Coleoptera: Chrysomelidae). Entomol. Exp. Appl. 131, 308-319. doi: 10.1111/j.1570-7458.2009.00859.x

Meissle, M., Zünd, J., Waldburger, M., and Romeis, J. (2014). Development of Chrysoperla carnea (Stephens) (Neuroptera: Chrysopidae) on pollen from Bt-transgenic and conventional maize. Sci. Rep. 4:5900. doi: 10.1038/srep05900

Meyer, H. (2011). Systemic risks of genetically modified crops: the need for new approaches to risk assessment. Environ. Sci. Eur. 23:7. doi: 10.1186/21904715-23-7

Naranjo, S. E. (2005). Long-term assessment of the effects of transgenic Bt cotton on the function of the natural enemy community. Environ. Entomol. 34, 1211-1223. doi: 10.1603/0046-225X(2005)034[1211:LAOTEO]2.0.CO;2

Naranjo, S. E. (2009). Impacts of Bt crops on non-target organisms and insecticide use patterns. CAB Rev. Perspect. Agric. Vet. Sci. Nutrit. Nat. Resour. 4:011. doi: 10.1079/PAVSNNR20094011 
Naranjo, S. E., and Ellsworth, P. C. (2005). Mortality dynamics and population regulation in Bemisia tabaci. Entomol. Exp. Appl. 16, 93-108. doi: 10.1111/j.15707458.2005.00297.x

Nguyen, H. T., and Jehle, J. A. (2007). Quantitative analysis of the seasonal and tissue-specific expression of Cry1Ab in transgenic maize Mon810. J. Plant Dis. Prot. 114, 82-87.

Nienstedt, K. M., Brock, T. C. M., van Wensem, J., Montforts, M., Hart, A., Aagaard, A., et al. (2012). Development of a framework based on an ecosystem services approach for deriving specific protection goals for environmental risk assessment of pesticides. Sci. Total Environ. 415, 31-38. doi: 10.1016/j.scitotenv.2011.05.057

Obrist, L. B., Dutton, A., Albajes, R., and Bigler, F. (2006a). Exposure of arthropod predators to Cry1Ab toxin in Bt maize fields. Ecol. Entomol. 31, 143-154. doi: 10.1111/j.0307-6946.2006.00762.x

Obrist, L. B., Dutton, A., Romeis, J., and Bigler, F. (2006b). Biological activity of Cryl Ab toxin expressed by $\mathrm{Bt}$ maize following ingestion by herbivorous arthropods and exposure of the predator Chrysoperla carnea. Biocontrol 51, 31-48. doi: 10.1007/s10526-005-2936-8

Obrist, L. B., Kleim, H., Dutton, A., and Bigler, F. (2006c). Assessing the effects of Bt maize on the predatory mite Neoseiulus cucumeris. Exp. Appl. Acarol. 38, 125-139. doi: 10.1007/s10493-006-0008-0

Obrist, L. B., Klein, H., Dutton, A., and Bigler, F. (2005). Effects of Bt maize on Frankliniella tenuicornis and exposure of thrips predators to prey-mediated $\mathrm{Bt}$ toxin. Entomol. Exp. Appl. 115, 409-416. doi: 10.1111/j.1570-7458.2005.00298.x

Organisation for Economic Co-operation and Development (OECD). (2007). Consensus Document on Safety Information on Transgenic Plants Expressing Bacillus Thuringiensis-Derived Insect Control Protein. Series on Harmonisation of Regulatory Oversight in Biotechnology, No. 42. Paris: Organisation for Economic Co-operation and Development. Available online at: http://www.epa. gov/oppbppd1/biopesticides/pips/reg-biotech.pdf (Accessed July 3, 2014)

Pilcher, C. D., Obrycki, J. J., Rice, M. E., and Lewis, L. C. (1997). Preimaginal development, survival, and field abundance of insect predators on transgenic Bacillus thuringiensis corn. Environ. Entomol. 26, 446-454.

Pons, X., Lumbierres, B., López, C., and Albajes, R. (2005). Abundance of nontarget pests in transgenic Bt-maize: a farm scale study. Eur. J. Entomol. 102, 73-79. doi: 10.14411/eje.2005.010

Principi, M. M., and Canard, M. (1984). "Feeding habits," in Biology of Chrysopidae, eds M. Canard, Y. Séméria, and T. R. New (The Hague: Dr. W. Junk Publishers), 76-92.

Raps, A., Kehr, J., Gugerli, P., Moar, W. J., Bigler, F., and Hilbeck, A. (2001). Immunological analysis of phloem sap of Bacillus thuringiensis corn and of the non-target herbivore Rhopalosiphum padi (Homoptera: Aphididae) for the presence of Cry1Ab. Mol. Ecol. 10, 525-533. doi: 10.1046/j.1365-294x.2001. 01236.x

Raybould, A. (2010). Reducing uncertainty in regulatory decision-making for transgenic crops. More ecological research or clearer environmental risk assessment? GM Crops 1, 25-31. doi: 10.4161/gmcr.1.1.9776

Rodrigo-Simón, A., de Maagd, R. A., Avilla, C., Bakker, P. L., Molthoff, J., González-Zamora, J. E., et al. (2006). Lack of detrimental effects of Bacillus thuringiensis Cry toxins on the insect predator Chrysoperla carnea: a toxicological, histopathological, and biochemical approach. Appl. Environ. Microbiol. 72, 1595-1603. doi: 10.1128/AEM.72.2.15951603.2006

Romeis, J., Bartsch, D., Bigler, F., Candolfi, M. P., Gielkens, M. M. C., Hartley, S. E., et al. (2008). Assessment of risk of insect-resistant transgenic crops to nontarget arthropods. Nat. Biotechnol. 26, 203-208. doi: 10.1038/nbt1381

Romeis, J., Dutton, A., and Bigler, F. (2004). Bacillus thuringiensis toxin (CrylAb) has no direct effect on larvae of the green lacewing Chrysoperla carnea (Stephens) (Neuroptera: Chrysopidae). J. Insect Physiol. 50, 175-183. doi: 10.1016/j.jinsphys.2003.11.004

Romeis, J., Hellmich, R. L., Candolfi, M. P., Carstens, K., De Schrijver, A., Gatehouse, A. M. R., et al. (2011). Recommendations for the design of laboratory studies on non-target arthropods for risk assessment of genetically engineered plants. Transgenic Res. 20, 1-22. doi: 10.1007/s11248-0109446-x

Romeis, J., McLean, M. A., and Shelton, A. M. (2013). When bad science makes good headlines: Bt maize and regulatory bans. Nat. Biotechnol. 31, 386-387. doi: $10.1038 /$ nbt. 2578
Romeis, J., and Meissle, M. (2011). Non-target risk assessment of Bt crops-cry protein uptake by aphids. J. Appl. Entomol. 135, 1-6. doi: 10.1111/j.14390418.2010.01546.x

Romeis, J., Meissle, M., Álvarez-Alfageme, F., Bigler, F., Bohan, D. A., Devos, Y., et al. (2014). Potential use of an arthropod database to support the nontarget risk assessment and monitoring of transgenic plants. Transgenic Res. doi: 10.1007/s11248-014-9791-2. [Epub ahead of print].

Romeis, J., Meissle, M., and Bigler, F. (2006). Transgenic crops expressing Bacillus thuringiensis toxins and biological control. Nat. Biotechnol. 24, 63-71. doi: $10.1038 / \mathrm{nbt} 1180$

Rose, R. I. (ed.). (2007). White Paper on Tier-based Testing for the Effects of Proteinaceous Insecticidal Plant-incorporated Protectants on Non-target Invertebrates for Regulatory Risk Assessment. Washington, DC: USDA-APHIS and US Environmental Protection Agency. Available online: http://www.epa. gov/pesticides/biopesticides/pips/non-target-arthropods.pdf (Accessed July 31, 2014)

Rosenberg, M. S., Adams, D. C., and Gurevitch, J. (2000). MetaWin Version 2: Statistical Software for Meta-analysis. Sunderland, MA: Sinauer Associates, Inc.

Sanvido, O., Romeis, J., Gathmann, A., Gielkens, M., Raybould, A., and Bigler, F. (2012). Evaluating environmental risks of genetically modified cropsecological harm criteria for regulatory decision-making. Environ. Sci. Policy 15, 82-91. doi: 10.1016/j.envsci.2011.08.006

Schnepf, E., Crickmore, N., van Rie, J., Lereclus, D., Baum, J., Feitelson, J., et al. (1998). Bacillus thuringiensis and its pesticidal crystal proteins. Microbiol. Mol. Biol. Rev. 62, 775-806.

Sears, M. K., Hellmich, R. L., Stanley-Horn, D. E., Oberhauser, K. S., Pleasants, J. M., Mattila, H. R., et al. (2001). Impact of Bt con pollen on monarch butterfly populations: a risk assessment. Proc. Nat. Acad. Sci. U.S.A. 98, 11937-11942. doi: 10.1073/pnas. 211329998

Sheldon, J. K., and MacLeod, E. G. (1971). Studies on the biology of the Chrysopidae. 2nd. The feeding behavior of the adult of Chrysopa carnea (Neuroptera). Psyche 78, 107-121.

Székács, A., Lauber, E., Juracsek, J., and Darvas, B. (2010). Cry1Ab toxin production of MON810 transgenic maize. Environ. Tox. Chem. 29, 182-190 doi: $10.1002 /$ etc. 5

Then, C. (2010). Risk assessment of toxins derived from Bacillus thuringiensis synergism, efficacy, and selectivity. Environ. Sci. Pollut. Res. 17, 791-797. doi: 10.1007/s11356-009-0208-3

Tian, J.-C., Collins, H. L., Romeis, J., Naranjo, S. E., Hellmich, R. L., and Shelton, A. M. (2012). Using field-evolved resistance to CrylF maize in a lepidopteran pest to demonstrate no adverse effects of Cry1F on one of its major predators. Transgenic Res. 21, 1303-1310. doi: 10.1007/s11248-0129604-4

Tian, J.-C., Wang, X.-P., Long, L.-P., Romeis, J., Naranjo, S. E., Hellmich, R. L., et al. (2013). Bt crops producing CrylAc, Cry2Ab and Cry1F do not harm the green lacewing, Chrysoperla rufilabris. PLoS ONE 8:e60125. doi: 10.1371/journal.pone.0060125

Van Emden, H. F. (1999). Transgenic host plant resistance to insects-some reservations. Ann. Entomol. Soc. Am. 92, 788-797.

Villenave, J., Deutsch, B., Lodé, T., and Rat-Morris, E. (2006). Pollen preference of the Chrysoperla species (Neuroptera: Chrysopidae) occurring in the crop environment in western France. Eur. J. Entomol. 103, 771-777. doi: 10.14411/eje.2006.104

Vogt, H., Bigler, F., Brown, K., Candolfi, M. P., Kemmeter, F., Kühner, C. et al. (2000). "Laboratory method to test effects of plant protection products on larvae of Chrysoperla carnea (Neuroptera: Chrysopidae)," in Candolfi, Guidelines to Evaluate Side-Effects of Plant Protection Products to Non-target Arthropods, eds M. P. Candolfi, S. Blümel, R. Forster, F. M. Bakker, C. Grimm, S. A. Hassan, U. Heimbach, M. A. Mead-Briggs, B. Reber, R. Schmuck, and H. Vogt (IOBS/WPRS: Gent), 27-44.

Walker, B. H. (1992). Biodiversity and ecological redundancy. Conserv. Biol. 6, 18-23. doi: 10.1046/j.1523-1739.1992.610018.x

Weber, N., Halpin, C., Hannah, L. C., Jez, J. M., Kough, J., and Parrott, W. (2012). Crop genome plasticity and its relevance to food and feed safety of genetically engineered breeding stacks. Plant Physiol. 160, 1842-1853. doi: 10.1104/pp.112.204271

Wei, W., Schuler, T. H., Clark, S. J., Stewart, C. N. Jr., and Poppy, G. M. (2008). Movement of transgenic plant-expressed Bt CrylAc proteins 
through high trophic levels. J. Appl. Entomol. 132, 1-11. doi: 10.1111/j.14390418.2007.01242.x

Wolfenbarger, L. L., Naranjo, S. E., Lundgren, J. G., Bitzer, R. J., and Watrud, L. S. (2008). Bt crops effects on functional guilds of non-target arthropods: a meta-analysis. PLoS ONE 3:e2118. doi: 10.1371/journal.pone. 0002118

Yazlovetsky, I. G. (2001). "Features of the nutrition of Chrysopidae larvae and larval artificial diets," in Lacewings in the Crop Environment, eds P. McEwen, T. R. New, and A. E. Whittington (Cambridge: Cambridge University Press). 329-337.

Conflict of Interest Statement: The authors declare that the research was conducted in the absence of any commercial or financial relationships that could be construed as a potential conflict of interest.
Received: 19 May 2014; paper pending published: 03 July 2014; accepted: 22 July 2014; published online: 12 August 2014.

Citation: Romeis J, Meissle M, Naranjo SE, Li Y and Bigler F (2014) The end of a myth—Bt $(\mathrm{Cry} 1 \mathrm{Ab})$ maize does not harm green lacewings. Front. Plant Sci. 5:391. doi: $10.3389 /$ fpls.2014.00391

This article was submitted to Plant Biotechnology, a section of the journal Frontiers in Plant Science.

Copyright (C) 2014 Romeis, Meissle, Naranjo, Li and Bigler. This is an openaccess article distributed under the terms of the Creative Commons Attribution License (CC BY). The use, distribution or reproduction in other forums is permitted, provided the original author(s) or licensor are credited and that the original publication in this journal is cited, in accordance with accepted academic practice. No use, distribution or reproduction is permitted which does not comply with these terms. 